\title{
RESEARCH INTO FACTORS OF MUTUAL INFLUENCE OF GROUND WATERS QUALITY PARAMETERS ON CHOICE OF WATER CLEANSING TECHNOLOGIES
}

\author{
A. Kvartenko \\ National University of Water and Environmental Engineering, Rivne, Ukraine \\ e-mail: as-755@rambler.ru
}

The aim of the paper is to study the mutual influence of water quality basic parameters on the selection of technological schemes and water treatment equipment, the development of the classifier of treatment technologies for multi-component ground waters. As a result of analytical and experimental research carried out the actuality of this task was established. The interconnection of the complex of compounds dissolved in ground waters (of iron, manganese, organic acids, gases, ammonium nitrogen, fluorine) with values of $\mathrm{pH}$-Eh and bicarbonate alkalinity of medium with the presence of iron bacteria is shown. Main environmental factors influencing the intensiveness of metabolism of iron bacteria are shown. The structural scheme of the interconnection of components of underground waters with various physico-chemical compositions is developed. By results of studies a classifier for treatment technologies for multi-component hydro-carbonate underground waters was developed. It is determined that in substantiating the choice of the efficient water treatment technology it is necessary to take into account such factors: form of iron compounds in natural water, value of $\mathrm{pH}$-Eh and bicarbonate alkalinity, presence of dissolved organic substances and gases.

Key words: choice of water treatment technologies, classifier of technologies.

\section{Introduction}

Ground waters are a complicated multi-component system which includes an interrelated complex of dissolved nonorganic and organic substances, gases, micro - flora. In work [1] data are shown concerning the effect of some factors, namely of ions of $\mathrm{Fe}, \mathrm{Mn}, \mathrm{F}$, of free carbon and $\mathrm{pH}$ on the selection of a water treatment technological scheme. In work [2] the question was clarified in more detail concerning the choice of $\mathrm{CO}_{2}$ removal technology in processes of deironingdemanganizing depending on the carbonate alkalinity and $\mathrm{pH}$ of water. The classification is given of iron containing waters from the point of view of selecting water cleansing technologies in which chemical indices were stressed of the importance of alkalinity factor. The influence is shown of some values of physico-chemical indices of water (the content of Fe, Mn ions, of dissolved oxygen, of alkalinity values, of medium $\mathrm{pH}$, redox potential $(\mathrm{Eh})$ on selecting the technology of deironing demanganizing. However, the question is not considered of differentiating technologies by the quantitative condition of dissolved organic substances, of iron-humin complexes, of hydrogen sulfide, of free carbon dioxide, of ammonia, of phenols. As in the work [1] the factor is not clarified of the mutual influence of these indices on selecting water treatment technologies.

At present there are several classifiers for methods and technologies of treating underground waters developed by L.A.Kulsky, G.I.Nikoladze, M.G.Zhurba, J.M.Govorova, Dzyubo [1, 2, 3, 4].

The use of L.A.Kulsky classification in designing water treatment stations permits in the first approximation to carry out the substantiation of methods use [3]. In designing new and reconstructing acting water treatment stations besides the phase dispersion condition of admixtures it is necessary to take into account the range of concentrations of compounds of natural and anthropogenic origin which are removed and also their interrelation in natural waters.

In the classifier of technologies by G.I.Nikoladze conditions were developed of their application for deironing, demanganizing and defluorinizing of underground waters considering 
values of redox potential, alkalinity, temperature, permanganate oxidation, presence of dissolved gasses, and also of forms of compounds of iron and manganese [2]. This classifier does not take into account optimum boundaries of bicarbonate alkalinity; $\mathrm{pH}$-Eh values of water system to use recommended technologies; parameters limits are exceeded for a number of technologies; the possibility is not considered of the available anthropogenic admixtures in underground waters and their interrelation with natural pollutions.

The classifier proposed by M.G. Zhurba of technologies for treating underground waters represents itself a systematic set of technological schemes with the distinct determination of their location depending on the values of defining ingredients both of natural and anthropogenic origin, the time factor of their presence in a given concentrations interval [1]. It is to be noted that in selecting the general technological treatment scheme as a basis is adopted a class and subclass of natural pollutions by groups and subgroups. In this classifier gradations are not accounted for of natural waters by redox potential, bicarbonate alkalinity, aggressiveness degree. The effect of these factors is not shown on the selection and operation efficiency of suggested technological schemes. Besides, the question is not considered of simultaneous presence in underground waters of iron compounds in mineral and complexly organic forms. Limiting concentrations are absent by hydrogen index $\mathrm{pH}$, the possible redistribution is not considered of quantitative indices of ingredients between classes of underground waters. This fact complicates the choice of technologies under different parameters of water quality than in the basic classification.

The statement of the problem. On the basis of the analysis done of literature sources it is established that the study of the mutual influence of physico-chemical indices of water quality with the available microbiological component is an urgent task in selecting the most efficient water treatment technologies. On the basis of the analysis of existing classifiers of technologies the author proposed the direction for their development and improvement.

The aim of this paper is the research into the mutual effect of basic indices of water quality on selecting, by the developed classifier of technologies, schemes and water purification equipment.

The objects of research were underground waters on which are based systems of water supply for a number of settlements in Ukraine.

Results and their discussion. By results of the survey carried out of preset day studies it is possible to draw such conclusions. Corresponding to [5] the system of iron, organic substances and hydrogen in underground waters is partially potential defining. The enrichment of underground waters by iron takes place as a result of the processes of leaching and dissolution of iron minerals under the action of carbon dioxide and organic compounds which are comprised in weak swamps and forest lakes. The forms of iron presence in natural waters are rather various: free ions, hydroxide complexes, complexes with nonorganic and organic ligands $[2,3,4,6]$. They depend on geochemical properties of underground waters, namely, $\mathrm{pH}$-Eh values of water medium $[2,4,5]$. By data [5] we created a set of the stability of basic iron compounds in natural waters:

$$
\begin{aligned}
& \mathrm{FeFA}(\mathrm{OH})_{2}^{-}>\mathrm{Fe}(\mathrm{OH})_{3}>\mathrm{Fe}(\mathrm{OH})_{3}^{+}>\mathrm{FeFAOH}>\mathrm{Fe}(\mathrm{FA})_{2}^{-}>\mathrm{FeOH}^{2+}> \\
& \mathrm{FeCO}_{3}^{+}>\mathrm{Fe}(\mathrm{HS})_{2}>\mathrm{Fe}(\mathrm{OH})_{2}>\mathrm{FeCO}_{3}(\mathrm{FeFA})>\mathrm{FeOH}^{+}>\mathrm{FeSO}_{4}>\mathrm{FeCl}_{3}
\end{aligned}
$$

As is seen, the most stable are iron organic compounds, hydroxide complexes and iron hydroxide (III). Humin acids create internally comprehensive compounds with many metals which depending on $\mathrm{pH}$ medium acquire greater mobility or form stable, non-dissolved in water compounds. Here, humin substances not only actively react with cations but also with oxides and 
hydroxides of metals. The activity of cations before forming complexes is presented by the following series :

$$
\mathrm{Fe}^{3+}>\mathrm{Al}^{3+}>\mathrm{Pb}^{2+}>\mathrm{Cu}^{2+}>\mathrm{Zn}^{2+}>\mathrm{Fe}^{2+}>\mathrm{Ca}^{2+}>\mathrm{Mg}^{2+}>\mathrm{NH}_{4}^{+}>\mathrm{Na}^{+}
$$

Infiltration flows containing humin and 'fulvic acids from swamp and forest lake waters penetrating into the depth of water bearing layers, reacting into the interaction with minerals are able to remove from them iron and manganese forming compounds which may move to great distances. Dissolved organic substances in the form of iron humates and fulvates render underground waters colour and in some cases may be referred to very coloured ones.

Less stable are mineral compounds of iron. In waters with insignificant content of organic compounds the nonorganic condition of iron creates the following series:

$$
\mathrm{Fe}^{2+}>>\mathrm{Fe}(\mathrm{OH})^{+}>\mathrm{FeCO}_{3}^{+} ; \mathrm{FeCO}_{3}>\mathrm{FeSO}_{4}
$$

The share of complex compounds of Fe-FA (iron fulvic acids) in such waters constitutes 10$15 \%$ of the total iron concentration. The decreased concentration of $\mathrm{Fe}^{2+}$ occurs with decreased $\mathrm{pH}$ and transformation:

$$
\begin{gathered}
\mathrm{Fe}_{2} \mathrm{O}_{3}+6 \mathrm{H}^{+}+2 \bar{e} \leftrightarrow 2 \mathrm{Fe}^{2+}+3 \mathrm{H}_{2} \mathrm{O} \\
\mathrm{FeCO}_{3}+\mathrm{H}_{2} \mathrm{O}+\mathrm{CO}_{2}=\mathrm{Fe}^{2+}+2 \mathrm{HCO}_{3}^{-} \\
\mathrm{FeCO}_{3}+\mathrm{H}^{+}=\mathrm{Fe}^{2+}+\mathrm{HCO}_{3}
\end{gathered}
$$

As is seen from equations, the quantitative content of $\mathrm{Fe}^{2+}$ in underground waters is directly connected with $\mathrm{pH}$ and $\mathrm{Eh}$ of the medium, with carbon dioxide which is an important factor for holding iron ions in a dissolved condition [2]. The source of carbon dioxide may be both organic and mineral substances comprising the composition of water bearing layer. The change of iron concentration is controlled by the balance of carbonate system:

$$
\begin{gathered}
4 \mathrm{Fe}^{2+}+8 \mathrm{HCO}_{3}^{-}+\mathrm{O}_{2} \leftrightarrow \mathrm{Fe}(\mathrm{OH})_{3}+8 \mathrm{CO}_{2} \\
\mathrm{Fe}^{2+}+2 \mathrm{HCO}_{3}^{-} \leftrightarrow \mathrm{FeCO}_{3}+\mathrm{CO}_{2}+\mathrm{H}_{2} \mathrm{O}
\end{gathered}
$$

From these reverse reactions it is seen that under the absence of carbon dioxide iron settles in the form of hydroxide or carbonate. Under great concentrations of free carbon dioxide the balance moves to the left and in water the content of $\mathrm{Fe}^{2+}$ grows. In water solutions of carbon acidic compounds there is a dynamic balance between various forms of carbon acid:

$$
2 \mathrm{HCO}_{3}^{-} \leftrightarrow \mathrm{CO}_{3}^{2-}+\mathrm{CO}_{2}+\mathrm{H}_{2} \mathrm{O}
$$

To support in a solution the corresponding concentration of bicarbonate ions the necessary condition is the presence of the corresponding concentration of free carbon dioxide. Under the increased concentration water acquires aggressive properties and requires stabilization preparation. With increased $\mathrm{pH}$ values there takes place the decreased share of $\mathrm{CO}_{2}{ }^{\text {free }}$ with the simultaneous increase of bicarbonate ions. Under $\mathrm{pH}=6,5$ these shares equalize, and with subsequent increased $\mathrm{pH}-$ the concentration of bicarbonate ions increases. With $\mathrm{pH}=8,3-8,4$ practically all available in 
water carbon acid is presented in the form of bicarbonate ions (98\%). Under further increase of $\mathrm{pH}$ values the share of bicarbonate ions decreases with the simultaneous increase of carbonate ions part. An important connecting link in the system $\mathrm{Fe}-\mathrm{pH}-\mathrm{CO}_{2}-\mathrm{OS}$ is water bicarbonate alkalinity. As was shown in [2] the removal of aggressive carbon dioxide directly depends on water alkalinity. From Allopo-Dyubena diagram [2] it is seen that the application of aeration method under the preparation of aggressive underground waters permits to get water with non-aggressive properties with values of bicarbonate alkalinity $>2,0 \mathrm{mg}-\mathrm{eq} / \mathrm{dm}^{3}$. Neutral waters with bicarbonate alkalinity $<2,0 \mathrm{mg}-\mathrm{eq} / \mathrm{dm}^{3}$ as a result of aeration require aggressive properties in relation to metal and concrete. Thus, to determine the possibility of oxidizing ions $\mathrm{Fe}$ and $\mathrm{Mn}$ with the help of aeration method it is necessary to know the value of carbonate rigidity of water. Removal and transformation of iron ions into non-soluble form is possible to be conducted with the help of aeration method only for waters with bicarbonate alkalinity $>2,0 \mathrm{mg}$-eq $/ \mathrm{dm}^{3}$ and under the absence of soluble organic substances.

Besides the interaction of physico - chemical factors and ingredients an important factor in the system is iron and manganese oxidizing bacteria $[7,10,11]$, the quantitative development of which depending on $\mathrm{pH}$ alkalinity is shown in fig. 1 . To build the cellular mass microorganisms use carbon. Microorganisms of Gallionella - autotrophs which use as a carbon source nonorganic substances (hydrocarbonates, carbon dioxide) [8, 9]. Microorganisms of the type Lepthothrix, Crenothrix - heterotrophs which in the capacity of carbon source use organic substances. At the boundary of oxidizing and restoration zones under neutral values of $\mathrm{pH}$ are regions of the activity of iron bacteria of types Lepthothrix, Gallionella - most adopted in the capacity of the bacteria consortium for treating natural waters which are used for drinking water supply (fig.2).

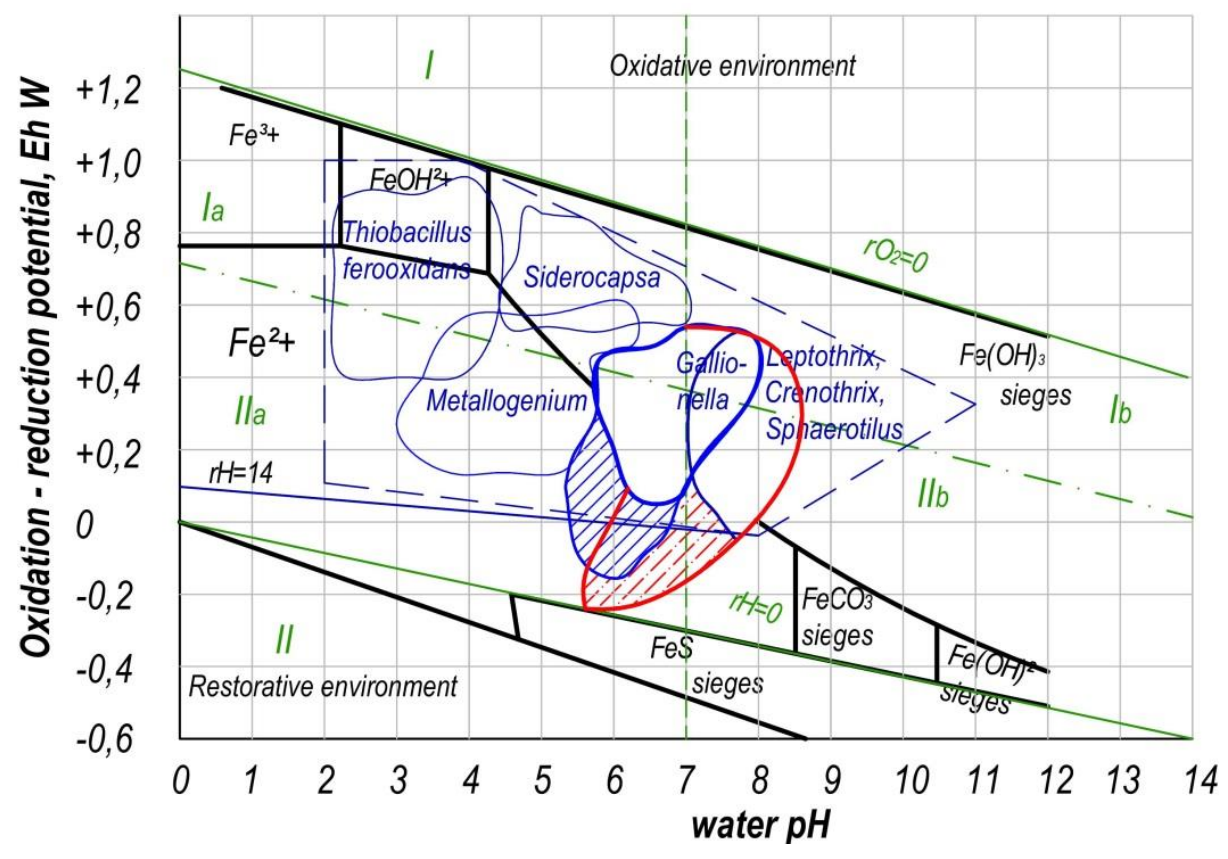

Fig.1. Fields of iron bacteria availability (by lines are distinguished fields researched by author)

In correspondence with [7, 14] the area of the distribution of Gallionella type is in the region of $\mathrm{pH}=5,8 \ldots 7,5$ and redox potential within $-100 \ldots 350 \mathrm{mV}$. To the said perimeters corresponds the further percentage of concentrations of free carbon dioxide and bicarbonates: $70 \%$ under $\mathrm{pH}=6,0$ and $20 \% \mathrm{pH}=7$ of effluent water. The effect of bicarbonate alkalinity on the development of iron 
bacteria under various $\mathrm{pH}$ values of effluent water was studied in our works [15]. The area of developing iron bacteria of Lepthothrix, Crenothrix type is in the region of values $\mathrm{pH}=6,0 \ldots 7,7$ and $\mathrm{Eh}=-100 \ldots 300 \mathrm{mV}$. Low values of Eh indicate the presence in underground waters of dissolved organic substances which together with $\mathrm{Fe}$ ions may form complex organic compounds within $\mathrm{pH}=6,0 \ldots 7,0$ and $\mathrm{Eh}<200 \mathrm{mV}$ and $\mathrm{pH}<5,0$ and $\mathrm{Eh}=200 \ldots 400 \mathrm{mV}$. The region within values $\mathrm{pH}=6,0 \ldots 7,5$ and $\mathrm{Eh}=200 \ldots 400 \mathrm{mV}$ in correspondence with [2] is in the field of forming iron hydroxide $\mathrm{Fe}(\mathrm{OH})_{3}$.

Under the availability in effluent water of nonorganic iron compounds and alkalinity $>6,0$ $\mathrm{mg}$-eq $/ \mathrm{dm}^{3}$ this region is within using physico-chemical methods of water deironing while under the presence of dissolved organic compounds air oxygen supplied to the system of treatment will not be enough for oxidizing complexly organic compounds and the oxidation mechanism will develop by peroxide way $[12,14]$.

Main factors of environment influencing the intensity of iron bacteria metabolism are shown in table 1 .

By results of analytical, theoretical and experimental studies carried out we developed the block-scheme of the interaction of ingredients dissolved in underground waters (fig.2).

Having studied the interconnection between ingredients, their stability boundaries, reactivity capability and also the possibility for mutual removal it is possible to draw the conclusion that while substantiating the selection of the efficient technology of water purification it is necessary to consider such parameters: the form of the displacement of pollutants in natural water; the possibility of developing the technological scheme taking into account bio-physico-chemical processes with the minimal use of chemical reagents; the type of an oxidizer:

a) of natural character - air oxygen which is introduced into the system as a result of simplified or deep aeration; hydrogen peroxide which is formed as a result of bacteria life activity;

b) of technical character - technical oxygen, ozone, potassium permanganate, chlorine, sodium hypochlorite, active radicals kept as a result of the process of hydro dynamic cavitation; the number of devices degrees for conducting processes of treatment and the necessity of stabilization of water preparation.

By results of investigations the author had proposed the classifier of technologies for water cleansing of multi-component hydro-carbonate underground waters which comprise the basis of underground waters of North Western regions of Ukraine. The classifier of technologies consists of four classes, four subclasses and three defining components. The division into classes is taken by standard classification of natural waters by active reaction of $\mathrm{pH}$ by which underground waters are grouped into such taxons: 1 - weak acidic waters $(\mathrm{pH}=5,0 \ldots 6,5)$; II - neutral waters $(\mathrm{pH}=6,5 \ldots 7,5)$; III - weak alkaline waters $(\mathrm{pH}=7,5 \ldots 8,5)$; IV - alkaline waters $(\mathrm{pH}=8,5 \ldots 9,5)$. In the capacity of defining components we chose the systems of organic substances and iron which by data [5] are potential defining for underground non-oxygen and non-sulfide waters, and also the system of non-carbonate alkalinity which is by [2] is a defining factor in selecting technological schemes of deironing. In the classifier a possible combinatorics is taken into account of the displacement of defining factors in different by $\mathrm{pH}$ value classes of underground waters. Proceeding from the received variability of the qualitative composition of underground waters were proposed unified technologies and respective combinatorics of water treatment methods.

The conditions of applying technological schemes in each class are singled out into separate blocks. The first block - general characteristics of treated water in a respective class (I - IV), the first defining component - the permanganate oxidation with a respective subclass of quality (I IV), the value of redox potential and possible forms of iron compounds existence. The second block renders water characteristics within values of the previous block by the second defining component 
- bicarbonate alkalinity with respective subclasses of water quality (I - IV) and by the aggressive properties of water in relation to metal and concrete. The third block considers subclasses of water quality (I - IV) by the third defining component - compounds of iron and manganese, blockschemes are given of proposed technologies and methods of water treatment used in them. The number of blocks is connected with the formed geochemical index of the quality of natural hydrocarbonate underground waters of the region researched.

Table 1.

Factors of exterior impact on intensification of processes for iron bacteria metabolism

\begin{tabular}{|c|c|c|c|}
\hline Factor & $\begin{array}{c}\text { Type of iron } \\
\text { bacteria }\end{array}$ & Role & $\begin{array}{c}\text { Methods for } \\
\text { controlling factor }\end{array}$ \\
\hline 1 & 2 & 3 & 4 \\
\hline $\begin{array}{lr}\text { Composition } & \text { and } \\
\text { concentration } & \text { of } \\
\text { consumptive } & \end{array}$ & Gallionella & & \\
\hline $\begin{array}{lr}\text { substances: } & \\
\text { 1. } \mathrm{Fe}\left(\mathrm{HCO}_{3}\right)_{2} ; & \mathrm{CO}_{2} \\
\text { 2. Additional source of } \\
\text { neorganic } & \text { carbon } \\
\mathrm{Na}_{2} \mathrm{CO}_{3} & \\
\text { 3. } & \text { Easily } \\
\text { oxidized organic } & \\
\text { substances; } & \\
\begin{array}{l}\text { 4. Fe-HA (iron } \\
\text { acids); Fumic } \\
\text { fulvic acids) }\end{array} & \text { (iron } \\
\end{array}$ & $\begin{array}{l}\text { Lepthothrix } \\
\text { Crenothrix }\end{array}$ & $\begin{array}{l}\text { Provides metabolism of } \\
\text { chemical reactions }\end{array}$ & $\begin{array}{l}\text { Supply of outlet water } \\
\text { with constant rate } \\
\text { which permits to } \\
\text { support continuity of } \\
\text { process }\end{array}$ \\
\hline $\mathrm{pH}$ & \multirow{3}{*}{$\begin{array}{l}\text { Gallionella, } \\
\text { Lepthothrix } \\
\text { Crenothrix }\end{array}$} & Optimizes the rate of & Regulated \\
\hline $\mathrm{Eh}$ & & $\begin{array}{l}\text { under } p H>7 \ldots 7,5 \text { chemical } \\
\text { oxidization competes with } \\
\text { biological }\end{array}$ & $\begin{array}{l}\text { intensiveness of } \\
\text { aeration, by addition of } \\
\text { solution } \mathrm{Na}_{2} \mathrm{CO}_{3}\end{array}$ \\
\hline $\begin{array}{c}\text { Content of dissolved } \\
\text { oxygen }\end{array}$ & & $\begin{array}{l}\text { 1.Acceptor of electrons for } \\
\text { biochemical oxidization; } \\
\text { 2.Influences microbiological } \\
\text { activity }\end{array}$ & $\begin{array}{lr}\text { Regulated } & \text { by } \\
\text { intensiveness } & \text { of } \\
\text { aeration } & \text { and } \\
\text { concentration } & \text { of } \\
\text { dissolved oxygen } & \end{array}$ \\
\hline $\begin{array}{l}\text { Diversity of } \\
\text { microorganisms }\end{array}$ & $\begin{array}{l}\text { Gallionella, } \\
\text { Lepthothrix, } \\
\text { Crenothrix, } \\
\text { Clonothrix, } \\
\text { Siderococcus }\end{array}$ & $\begin{array}{l}\text { Consortiums of } \\
\text { microorganisms are more } \\
\text { stable and efficient than pure } \\
\text { cultures }\end{array}$ & $\begin{array}{l}\text { 1. Creation of } \\
\text { aerophile, } \\
\text { microaerophile } \\
\text { conditions by loading } \\
\text { height. } \\
2 . \text { Use of various } \\
\text { sources of carbon }\end{array}$ \\
\hline
\end{tabular}




\begin{tabular}{|c|c|c|c|}
\hline 1 & 2 & 3 & 4 \\
\hline $\begin{array}{c}\text { Concentration of } \\
\text { metabolism products }\end{array}$ & $\begin{array}{l}\text { Lepthothrix, } \\
\text { Crenothrix }\end{array}$ & \multirow[t]{2}{*}{$\begin{array}{l}\text { Deceleration of biochemical } \\
\text { processes acceleration }\end{array}$} & $\begin{array}{l}\text { 1. Supporting } \\
\text { optimal rate of } \\
\text { filtration (supply } \\
\text { of outlet water } \\
\text { from } \mathrm{Fe}^{2+} \text { to } \\
\text { microorganisms } \\
\text { extracting } \mathrm{H}_{2} \mathrm{O}_{2} \\
\text { 2. Introduction of } \\
\text { inhibitors of catalase } \\
\text { extraction }\end{array}$ \\
\hline $\begin{array}{l}\text { Impact of permanent } \\
\text { magnetic field }\end{array}$ & $\begin{array}{l}\text { Gallionella, } \\
\text { Lepthothrix, } \\
\text { Crenothrix, } \\
\text { Clonothrx }\end{array}$ & & $\begin{array}{lr}\text { Regulation } & \text { of } \\
\text { magnetic } & \text { field } \\
\text { strength } & \end{array}$ \\
\hline Osmosis pressure & \multirow{2}{*}{$\begin{array}{l}\text { Gallionella, } \\
\text { Lepthothrix, } \\
\text { Crenothrix, } \\
\text { Clonothrix }\end{array}$} & $\begin{array}{l}\text { Determines boundaries of } \\
\text { microorganisms life activity }\end{array}$ & $\begin{array}{l}\text { Supported at constant } \\
\text { level by way of } \\
\text { correcting filtration } \\
\text { rate }\end{array}$ \\
\hline Possibility of adaptation & & $\begin{array}{l}\text { Iron bacteria specific for a } \\
\text { given natural source are most } \\
\text { adapted for cultivation }\end{array}$ & $\begin{array}{l}\text { Supporting optimal } \\
\text { parameters for } \\
\text { developing } \\
\text { determined species of } \\
\text { microorganisms }\end{array}$ \\
\hline
\end{tabular}

Taking in the capacity of basic criterion for classes of the quality of hydro-carbonate underground waters by acidic - alkaline condition ( $\mathrm{pH}$ values) is explained by such considerations. Firstly, by the fact that $\mathrm{pH}$ value is one of three basic indices along with redox conditions (Eh value) and the sum of dissolved substance characterizing the condition of geochemical medium in water. Secondly, by the fact that along with Eh it renders the direct influence on the state in water medium of groups of various metal cations $(\mathrm{Fe}, \mathrm{Mn})$ in the restoration or oxidation condition and also areas of developing various types of iron and manganese oxidizing bacteria. Thirdly, by the fact that it influences the condition of carbonate system, the percentage interrelationship of free carbon dioxide, hydro-carbonates, carbonates. Fourthly, - it influences the concentration of various sulfuric compounds in water $\left(\mathrm{S}, \mathrm{HS}, \mathrm{H}_{2} \mathrm{~S}\right)$. Thus, with $\mathrm{pH}=5,0 \ldots 6,0$ in underground waters there is basically $\mathrm{H}_{2} \mathrm{~S}$, with $\mathrm{pH}=7$ the interrelation between $\mathrm{HS}$ and $\mathrm{H}_{2} \mathrm{~S}$ is $0,5 \times 0,5$, with $\mathrm{pH}=8$ correspondingly $0,9 \times 0,1$. Fifthly, it influences the state in underground waters of nitrogen ammonia compounds: with decreased $\mathrm{pH}$ concentrations of free ammonia decrease and the content of $\mathrm{NH}_{4}{ }^{+}$ cations increases. Sixthly, the formation of complexes $\mathrm{FeS}, \mathrm{Fe}(\mathrm{HS})_{\mathrm{n}}{ }^{2-\mathrm{n}}$ depends also on $\mathrm{pH}$ value. Seventhly values of $\mathrm{pH}-\mathrm{Eh}$, the chemical composition of water and temperature are basic physicochemical factors for forming organic substances and complex compounds in underground waters. Thus, under $\mathrm{pH}>4,5$ and $\mathrm{Eh}<-200 \mathrm{mB}$ in underground waters are formed compounds $\mathrm{FeS}$; under $\mathrm{pH}<6.0$ - complexes $\mathrm{Fe}^{2+}$ - FA (fulvic acids); under $\mathrm{pH}=6,0 \ldots 7,2$ complexes $\mathrm{Fe}(\mathrm{OH})_{3}$ - FA; under values $\mathrm{pH}>7,2$ there takes place the dissolution of humin compounds $\mathrm{Fe}^{3+}$. 


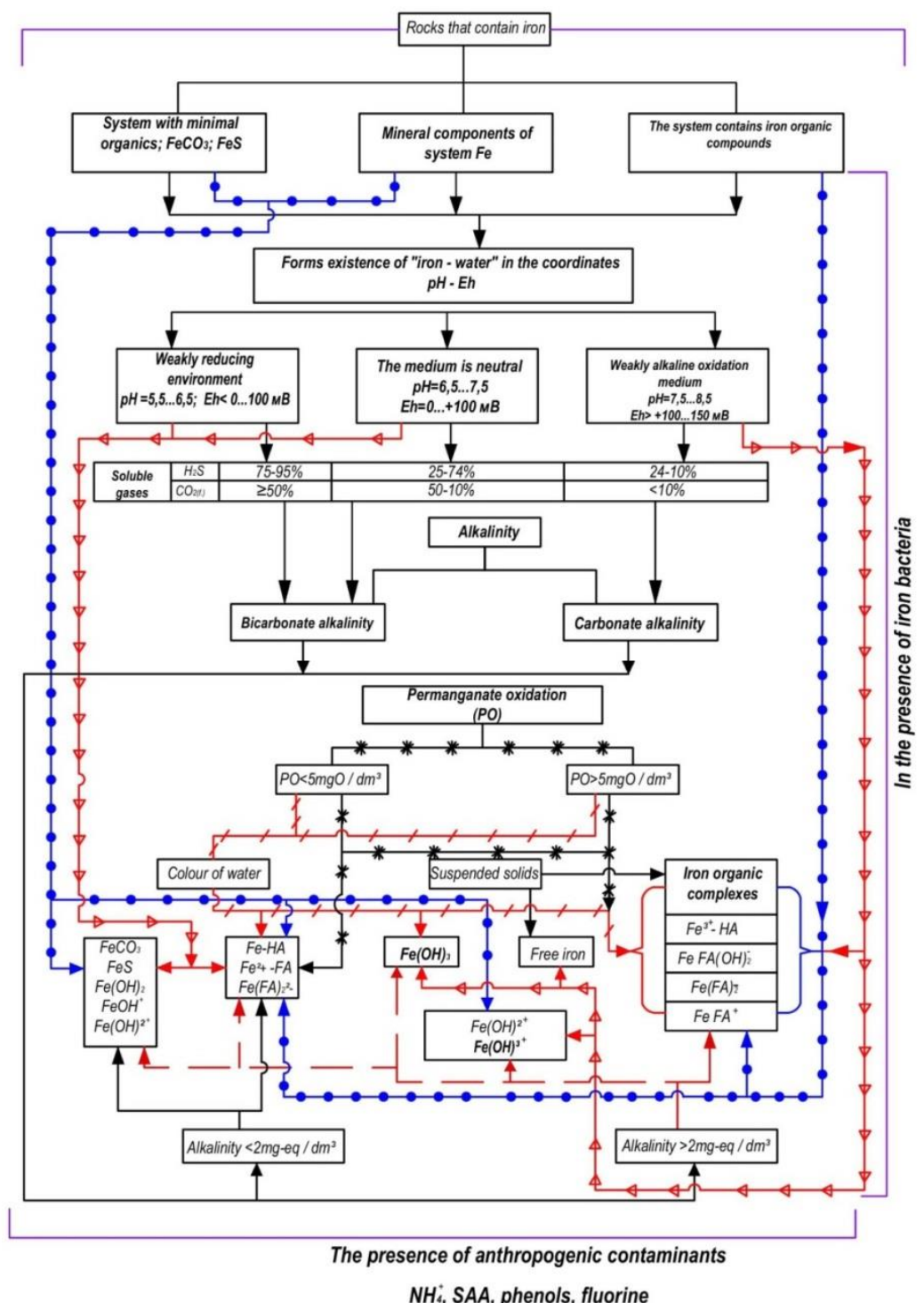

Fig.2. Structural scheme of mutual connection of ingredients comprising the composition of underground waters of different physico-chemical composition

The first defining component - permanganate oxidation characterizes the presence in water of easily oxidized organic substances. It influences the redox state of underground waters as a result of the changed interrelation between oxidized and restored forms of elements resulting in the change of Eh value.

Under their action there takes place the transformation of redox conditions into negative values of redox potential with the wide variation of $\mathrm{pH}$. Such change of redox situation is accompanied by the change of the interrelationship of iron forms of $\mathrm{Fe}^{2+}$ and $\mathrm{Fe}^{3+}$. There takes place the formation of more dissolved and mobile compounds of bivalent iron and the decrease of the content of three-valent iron compounds:

$$
\begin{aligned}
& 4 \mathrm{Fe}^{3+}+\mathrm{C}_{\text {org }}+2 \mathrm{H}_{2} \mathrm{O}=4 \mathrm{Fe}^{2+}+\mathrm{CO}_{2}+4 \mathrm{H}^{+} \\
& \text {and } \mathrm{Fe}^{2+}+3 \mathrm{H}_{2} \mathrm{O}=\mathrm{Fe}(\mathrm{OH})_{3}+3 \mathrm{H}^{+}+\mathrm{e}^{-}
\end{aligned}
$$


Organic compounds of FA are a forming system for $\mathrm{pH}=5,0 \ldots 6,0$. The presence of FA pushes the region of $\mathrm{Fe}^{2+}$ existence in underground waters for $\mathrm{pH}=7,0$. Besides, the interrelation $\mathrm{FA} / \mathrm{Fe}^{3+}$ influences the velocity of hydrolysis $\mathrm{Fe}^{3+}-\mathrm{FA}$ and the condition of $\mathrm{Fe}^{3+}$ cations location in dissolved state.

The second defining component - bicarbonate alkalinity influences the selection of methods for deironing, the degree of the aggressiveness of underground waters, the rate of occurring biochemical, chemical reactions, the rate and completeness of occurring coagulation processes, the level of the removal of aggressive carbon dioxide. It is to be corrected during the process of water treatment.

The third defining component iron - is in underground waters in various forms, depending on $\mathrm{pH}$-Eh values of the medium, bicarbonate alkalinity, concentration of dissolved carbon dioxide, sulfuric and organic complexes, compounds FA and HA is to be removed in the process of water treatment.

Technologies presented in a classifier are based depending on indices of effluent water quality, on the application of combined water treatment methods.

The effectiveness of using existent methods of water treatment depends directly on the combinatorics of the qualitative composition of underground waters. In weak acidic waters $(\mathrm{pH}=5,5 \ldots 6,0)$ with the low alkaline reserve $\left(\mathrm{A}<2,0 \mathrm{mg}\right.$-eq/ $\left.\mathrm{dm}^{3}\right)$ oxidation of iron compounds by aeration methods is polluted due to the impossibility of removing the aggressive carbon dioxide [2]. In this case it is necessary to carry out alkalification with further biological treatment. The oxidation of iron compounds is conducted, mainly, by iron bacteria [8-12].

Under the availability in such waters of complexly organic iron compounds the method of aeration-catalytic oxidation gives no proper treatment effect [15]. Deironing is possible only with the use of reagents for alkalification, biological oxidation, coagulation, filtering, or using strong oxidizers- coagulants and filters $[1,2,15]$.

In neutral waters $(\mathrm{pH}=6,5 \ldots 7,5)$ with bicarbonate alkalinity $>2,0 \mathrm{mg}$-eq/ $/ \mathrm{dm}^{3}$ the aggressive carbon dioxide may be removed with the help of aeration resulting in $\mathrm{pH}-\mathrm{Eh}$ system shifting to the area with oxidizing properties. Iron oxidation may be implemented both by the simplified and deep aeration and also by the method of biological treatment depending on the concentration of iron in effluent water.

\title{
Conclusions
}

It is determined that in substantiating the selection of the technological scheme of water treatment it is necessary to establish forms of pollutants location and their interconnection with other parameters of water quality. Main factors are determined of the influence on the selection of the method of purification and on the intensification of the process of iron bacteria metabolism. A classifier is developed of technologies for treating multi-component underground waters.

\section{ДОСЛІДЖЕННЯ ФАКТОРІВ ВЗАЕМНОГО ВПЛИВУ ПАРАМЕТРІВ ЯКОСТІ ПІДЗЕМНИХ ВОД НА ВИБІР ТЕХНОЛОГІЙ ВОДООЧИЩЕННЯ}

\author{
О.М. Квартенко
}

Національний університет водного господарства та природокористування, м. Рівне, Україна e-mail:as-755@rambler.ru 
Метою даної роботи є дослідження взаємного впливу основних показників якості води на вибір технологічних схем та водоочисного обладнання, розробка класифікатора технологій очищення багатокомпонентних підземних вод. В результаті проведених аналітичних та експериментальних досліджень встановлена актуальність иього завдання. Наведено взаємозв'язок комплексу розчинених у підземних водах сполук (заліза, мангану, органічних кислот, газів, азот амонійного, фтору) із величинами pH - Eh, бікарбонатної лужності середовища та присутністю залізобактерій. Вказані основні фактори зовнішнього середовища, які впливають на інтенсивність метаболізму залізобактерій. Розроблена структурна схема взаємного зв'язку інгредієнтів які входять до складу підземних вод різного фізико - хімічного складу. За результатами досліджень, розроблено класифікатор технологій водоочищення багатокомпонентних гідрокарбонатних підземних вод. Показано, щчо ефективність використання існуючих методів водоочищення напряму залежить від комбінаторики якісного складу підземних вод. Встановлено, щзо при обтрунтуванні вибору ефективної технології водоочищення необхідно враховувати наступні фактори: форму сполук заліза у природній воді, величини рH - Eh та бікарбонатної лужності, наявність розчинних органічних речовин та газів.

Ключові слова: вибір технологій водопідготовки, класифікатор технологій.

\title{
ИССЛЕДОВАНИЕ ФАКТОРОВ ВЗАИМНОГО ВЛИЯНИЯ ПАРАМЕТРОВ КАЧЕСТВА ПОДЗЕМНЫХ ВОД НА ВЫБОР ТЕХНОЛОГИЙ ВОДООЧИСТКИ
}

\author{
А.Н. Квартенко \\ Национальный университет водного хозяйства и природопользования, г. Ровно, Украина \\ e-mail: as-755@rambler.ru
}

Целью данной работы является исследование взаимного влияния основных показателей качества воды на выбор технологических схем и водоочистного оборудования, разработка классификатора технологий очистки многокомпонентных подземных вод. В результате проведенных аналитических и экспериментальных исследований установлена актуальность этой задачи. Приведена взаимосвязь комплекса растворенных в подземных водах соединений (железа, марганиа, органических кислот, газов, азот аммонийного, фтора) с величинами рН - Еh, бикарбонатной щеллочности среды в присутствии железобактерий. Указаны основные факторы внешней среды, влияющие на интенсивность метаболизма железобактерий. Разработана структурная схема взаимосвязи ингредиентов входящих в состав подземных вод различного физико-химического состава. По результатам исследований разработан классификатор технологий водоочистки многокомпонентных гидрокарбонатных подземных вод. Показано, что эффективность использования существующих методов водоочистки напрямую зависит от комбинаторики качественного состава подземньх вод. Установлено, что при обосновании выбора эффективной технологии водоочистки необходимо учитьвать следующие факторы: форму соединений железа в природной воде, величинь $\mathrm{pH}-\mathrm{Eh} \mathrm{u}$ бикарбонатной щелочности, наличие растворимых органических веществ и газов.

Ключевые слова: выбор технологий водоочистки, классификатор технологий. 


\section{Bibliography}

1. Zhurba M. G. Water supply. Improvement of water quality. Textbook for high schools. Volume 2 / Zhurba M. G., Govorova Zh. M. - Moscow: Publisher ASV. - 2008. - 544 p.

2. Nikoladze G. I. Iron removal of natural and circulating waters / Nikoladze G.I. Moscow: Stroiizdat, -1978 . -160 p.

3. Kulsky L. A. Technology of natural water purification / Kulsky L. A., Strokach P. P. - High school. - Kiev. 1986. - 352 p.

4. Dziubo, V. V. Preparation of groundwater for drinking water supply in small settlements of the West Siberian region: the author's abstract. Dis. ... Dr. techn. Sciences. - St. Petersburg. - 2007. -37 p.

5. Tyutyunova F.I. Hydrogeochemistry of technogenesis. / Tyutyunova F.I. - M.: Science, $-1987,-335 \mathrm{p}$.

6. Iron removal of underground water for drinking purposes [monography]/ V. O. .Orlov, A. N. Kvartenko, S. Yu. Martynov, Yu.I.Hordiyenko. - Rivne: UDUVGP Publishing House, 2004. - 153 p.

7. Kvartenko A. N. The characteristics of groundwater in the North-Western regions of Ukraine and the technological schemes for their conditioning / A. N. Kvartenko // Problems of water supply, water use and hydropower. Scientific and Technical Collection. - K .: KNUCA, 2011. Viginal 16. P.32 - 40.

8. Kittner H. DieBemessung von Enteisenung filter./ H. Kittner// Wasserwirtschaft Wassertechnik. 1968. - no №8.

9. Czekalla, C., Quantitative Removal of Iron and Manganese by Microorganisms in Rapid Sand Filters (In Situ Investigations) / C. Czekalla, W. Mevius, H. Hanert// Water Supply. 1985. - vol. 3. - Berlin '"B', pp. 111- 123.

10. Mouchet, P. From Conventional to Biological Removal of Iron and Manganese in France/ P. Mouchet,// Journal of the American Water Works Association. - 1992 - vol. 84, no 4, p. 158-167.

11. Askerniia A. A. Microbiological aspects of natural underground water deironing and demanganation/ A. A. Askerniia, A. Iu.Sorokina, G.A.Dubinina// Vodosnabzhenie i Sanitarnaia Tekhnika. - 2014. - no. - 12 p. 14- 21

12. Dubinina G. A. Biology of iron bacteria and their role in the formation of ironmanganese ores: author's abstract. For the assignment of scientific. Degree of Doct. Biological Sciences: special. 03.02.03 / G.A. Dubinin. - Moscow. - 1977. - 64c.

13. Tamura T. Iron and manganese removal by iron bacteria in groundwater/ T. Tamura, T. Tsunai, Y. Ishimaru, A.Nakata// Suido Kyokai Zasshi (J. Japan Water Works Assoc.). - 1999 no. 68, p. $1-13$

14. Kvartenko A. N. Use of a fixed microflora for the purification of underground subshells with a high concentration of iron: Dis. for obtaining Sciences. degree candidate. Tech. Sciences: spec. 05.23.04 / A. N. Kvartenko. - Rivne, 1997. - 180 p.

15. Kvartenko, A. N. Research methods of treating water from underground zalizomistnyh ammonium compounds and ammonia [Text] / A. N. Kvartenko, L. A. Sabliy // Water and water treatment technology. Scientific and technical news. - 2016. - №1 (18). - P. $39-49$. 